\title{
USING COMIC STRIPS TO IMPROVE STUDENTS' MOTIVATION AND READING COMPREHENSION AT MA. RAUDLATUSSHIBYAN NW BELENCONG
}

\author{
Bq Zuhrotun Nafisah \& Aditya Pratama \\ UNDIKMA Mataram \\ baiq.nafisa@gmail.com, adityapratama920@gmail.com
}

\begin{abstract}
This research was aimed to know how comic strip can improve students' motivation and reading comprehension at MA. Raudlatusshibyan NW Belencong in academic year 2017/2018. The research design was classroom action research. It consists of one cycle, and the cycle consists of planning, action, observation, and reflection. The data were collected by using reading tests and questionnaire. The result study shown that comic strip improved students' motivation and reading comprehension. The percentage of students that got very high motivation after using Comic Strip in learning reading is $55 \%$ and $45 \%$ got high motivation. The result of the mean in post-test at cycle 1 is 77,9 while the students' bighest score was 88 and the lowest score was 52. The result of the test shown the abilities of the students were improved. There were 17 students or $85 \%$ out of the 20 students who reached the score of KKM while the rest of them there were 3 students or 15\% failed. It is indicated the improvement of student's reading comprehension and their motivation of English learning process.
\end{abstract}

Keywords: Comic Strip, Motivation and Reading Comprehension

\section{INTRODUCTION}

Language is an important thing in our life because if someone can not to mastering the language it is a serious case because someone can not to make some of conversation each other. There are 4 important skills in language such as: listening, speaking, reading and writing. Reading is one of an important skill in language and the function of reading is to know or to understand about something that someone writing in the book. According to Snow (2002: 11) Reading comprehension as the process of simultaneously extracting and constructing meaning through interaction and involvement with written language. It means reading absolutely something that good for someone that want to look for the knowledge and it is extraordinary achievement if they can understand the language that written use in the book and know about the meaning about something that they read. 
Reading is one of the important skills in mastering English. As Nunan in Rengur and Sugirin (2018) stated that reading needs recognition and explanation processes which require the readers' knowledge about the language structure used in the text and their knowledge about the given topic. Relevant background knowledge is an important factor in reading comprehension than grammatical complexity. In avoiding the complexity, the students have to comprehend the contents of the text. Without comprehending the contents of the text, students cannot achieve the purposes of reading.

Other factor that has an important role in reading comprehension is students' motivation. In line with Grabe and Stoller (2002) also emphasized that reading motivation is very important for students and it increases students' reading comprehension.

According to Jere (2004:3-4) motivation is theory construct used to explain the initiation, direction, intensity, persistence, and quality of behavior especially goal directed behavior. It means someone motivation it can be looked from someone behavior in everyday and their daily life. In mastering skill in language, someone also should be have something in their heart that make someone always feel interest about and something that their need is a motivation. Motivation is a something that cannot we are touch and see but we can feel it and motivation could have a good influence for someone because it has liaison with someone spirit and curious in learning. In this study motivation is a big thing that can support the research of researcher can be success.

Based on the researcher observation in MA Raudlatusshibyan NW Belencong, researcher found some problems in teaching reading. Problems that researcher found such as: students are weak in finding main idea and paraphrasing sentences. Here, researcher also found some of students' problem in their motivation such as: students were not interested and students' competence that still low in reading. This problem can be happened because the teaching media made students bored and not giving full attention to the teacher. The media that teacher used in the teaching reading is a textbook. The teacher was also difficult to find out the media that teacher will use in transferring knowledge. 
There are several media in teaching reading that can build students' motivation in the class in transferring knowledge and here the researcher used comic strip as the media to improve students' motivation and reading comprehension. Comic Strips play an essential role to support the teaching and learning process. It can be the effective media in increasing students' reading comprehension. Rokhayati and Utari (2014) stated that the use of comic strips as an English teaching media for students was effective. Thus, comic strips as the media in teaching students' reading comprehension should be implemented in the English classroom.

Comic strips create messages through story line and pictures. It has some benefits such as: helping students to comprehend the contents of the text, helping them to improve their ideas, increasing their interest in reading. Carry (2014) argues that in comic, readability measures are determined not only on words, but also on pictures. Here, pictures support the words to make the contents of the text becomes more comprehensible.

The researcher chose this media because the researcher thinks it is something that every people like to read because there are many pictures and researcher believe that this media can be maximal in receiving the knowledge from the teacher and will be succeeded in the practice.

\section{RESEARCH METHOD}

In this research, the researcher used Classroom Action Research (CAR). CAR is a research that examines some ideas in practice to change something in order to get the real research. Here researcher used qualitative approach and quantitative approach. According to Costello, (2003: 5) say that action research is referred to variously as a term, process, enquiry, approach, flexible spiral process and as cyclic. According to Costello (2003: 8) stated the 4 cycle in classroom action research such to planning, action, observation and reflecting. 


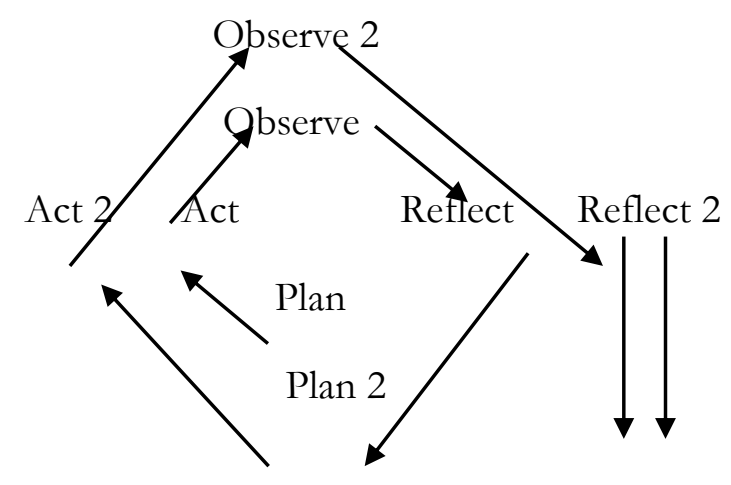

Figure 1. An extended action research model (Costello: 2003)

This research was conducted form March 2018 until April 2018 at MA Raudlatusshibyan NW Belencong. It is located in Gunung Sari, West Lombok.

The subject in this research were students of A class from first grade in MA Raudlatusshibyan NW Belencong which consists of 20 students and the object in this research is Comic Strip

In a research, instrument is an important thing in the research to got the data and after that analyze by the researcher. It also as a good way to know what exactly researcher need to collect the data. Here there are two kinds of instrument that researcher used to collect the data such as: reading test and questionnaire.

1. Reading Test

To know the improving of comic strip to students' motivation and reading comprehension, researcher gave some of exercises and consists of essay questions. There are 20 questions and the correct answer got 1 score and incorrect answer got 0 score, and the maximum score were 100.

2. Questionnaire

The questionnaire was given after reading test, the aim is to know the influence of using comic strip in improving students' motivation and reading comprehension. In this study, the researcher used open-close with form Likert scale to complete the data. Likert scale is used to measure the personality, opinion and people perception or group of people about social phenomenon and researcher have to provide the answer. Researcher used this model because the answer is made by the researcher which there are five 
categories like: very disagree, disagree, undecided, agree and very agree and consist 20 statements.

\section{Procedures of the Research}

This research was followed by several actions. They are planning, action, observation, and reflection which is adapted from Kemmis and Mc Taggart in (Castello, 2003: 5) design. In this case, the research was conducted in one cycles only. The researcher was used KKM from the school as instruction was $75 \%$. In cycle one, if the researcher got enough score more than KKM, means the researcher would not conducted the second cycle. Conducting one cycle to know the procedures of this present research is illustrated as follows:

1. Planning

In this activity, the researcher prepared as follow:

a) Designing lesson plan

b) Observational sheets

c) Test

2. Action

In this action is implementation of the plan. In this activity the researcher uses comic strip as a media in learning activity.

3. Observing

In this activity, the researcher was prepared the observational sheets and the researcher will conduct during the teaching learning process. The purpose would like to know the activity the students and also the writer prepare test.

4. Reflecting

In this activity, the researcher was conducted the reflection from the action, in the cycle one. It is intend to be use as a consideration to the material in the next cycle. 


\section{Techniques of Data Collection}

There are two techniques that researcher used to collect the data such as:

1. Post Test

Pos-test is the second step of collecting data in this researcher. This step is conducted after given the action. This test was given to find out the result of the research it has a positive or negative impact to the students'.

2. Questionnaire

According to Sugiyono (2011: 142)"questionnaire is technique of collecting data that done by giving set of written questions to answer by respondents". Here, questionnaire that used in this research is open-close questionnaire where is likert scale, is written of question to be answer by the students'. These instruments take all the students as the respondents. It applied at the preliminary study. Also, it used after classroom action research to know the students' respond toward the students' motivation and reading comprehension. The statement consisted of 20 statements.

\section{Technique of Data Analysis}

Several steps to look for the significance of the research are:

1. Quantitative

a. Mean

Mean is technical term for what is usually called the average or mean is divided as the sum of all the scores divided by the number of scores. To find out the value of mean the researcher use the formula below:

$\overline{\mathrm{X}}=\frac{\sum f i x i}{\sum f i}$

Where:

$\overline{\mathrm{X}} \quad$ : the symbol of mean

$\sum \quad$ : the symbol for summation

$x i \quad$ : For any score in the set

fi : Frequency

((Sugiyono, 2017: 54) 


\section{Qualitative}

Questionnaire is a technique collecting the data with given some question or statements for respondent. In this research the questionnaire used to support the main data by using description the media which involves the description and interpretation of the data. The researcher used questionnaire to find out students' motivation. In analyzing the students' motivation, the researcher used formula:

$$
\mathrm{P}=\frac{F}{N} X 100 \%
$$

Where:

$\mathrm{P}=$ the percentage

$\mathrm{F}=$ frequency of the percentage is being calculated

$\mathrm{N}=$ Number of cases

Next, based on the result of the percentage of the students' motivation, the researcher also used the criterion of score interpreting as follow:

Table 1. Criteria of Score Interpreting

\begin{tabular}{lc}
\hline Criteria & Score \\
Strongly agree & 5 \\
Agree & 4 \\
Uncertain & 3 \\
Disagree & 2 \\
Strongly Agree & 1 \\
\hline
\end{tabular}


After each answer is calculated, the score is processed based on the criterion of interpretation score as follow (Ridwan, 2005: 89):

Table 2. Percentage of Interpreting Score

\begin{tabular}{lc}
\hline Percentage & Criteria \\
$0 \%-25 \%$ & Very low \\
$26 \%-50 \%$ & Low \\
$51 \%-75 \%$ & Strong \\
$76 \%-100 \%$ & Very strong \\
\hline
\end{tabular}

\section{FINDING AND DISCUSSION}

From the class observation showed some problems that faced by the students both in motivation and the reading comprehension. It happened because of the media that the teacher used in teaching reading was inadequate.

First, the students had difficulties in finding and developing the main idea of the text. Most of the students need more time to think in finding the main idea. Second, the students had difficulties in paraphrasing the sentences: the sentences that the students produced was unwell-organized, they had problems in break the information from the text into separate sentences. Another problem that the researcher found was that they had low motivation in comprehending the reading text. These problems attracted the researcher's attention because reading is play an important role in learning process. As in line with Richards and Renandya in (Rengur and Sugirin, 2018: 239) stated that in many second or foreign language teaching situations, reading receives a special focus. The other reason stated by Hamer in Rengur and Sugirin, 2018: 239) stated that reading texts provide opportunities to study language such as vocabulary, grammar punctuation, and the way of constructing sentences, paragraphs, and texts.

After analyzing the observation result in the first cycle, the researcher found the students' progress in reading comprehension and their motivation. It showed that there were some improvements that achieved after doing the action. 


\section{The Result of Questionnaire}

The researcher used questionnaire method besides giving the test to the students. The researcher chose questionnaire as instrument to collect information from a large number of students and on the other side the students as respondents could complete and return it in certain period. The researcher wanted to underline here that the questionnaire would be used to measure the improvement of student's motivation along teaching learning process. It consists of 20 questions in the questionnaire based on the indicators of motivation.

Table 3. Interval score of students' motivation

\begin{tabular}{ccccc}
\hline Kelas Interval & & $\mathbf{X i}$ & $\mathbf{f i}$ & $\sum$ fixi \\
61 & 66 & 63.5 & 1 & 63.5 \\
67 & 72 & 69.5 & 6 & 417 \\
73 & 78 & 75.5 & 6 & 453 \\
79 & 84 & 81.5 & 6 & 489 \\
85 & 90 & 87.5 & 1 & 87.5 \\
& Jumlah & & 20 & 1510 \\
\hline
\end{tabular}

The result everage of questionnaire table is $X=\frac{1510}{20}=75.5$. So, based on the result above the percentage of students' everage or mean is $75.5 \%$ that is mean if the comic strip can improving students' motivation by using comic strip.

\section{The Result of Reading Test}

The researcher used the post-test to get the data or to know the result of using Comic Strip in reading is effective or not. The researcher used the post-test because the students should be answer any exercises and here the using of post-test as the evaluation and in the same time post test as instrument to collect information from a large number of students and on the other side the students as respondents could complete and return it in certain period. The other function of post test is to measure students understanding and students improving after teaching reading by using the comic strip as the media in 
the classroom. Post-test were consists of 20 questions in the post-test based on the indicators of reading.

Dealing with the improvement of students' reading comprehension, Comic Strip stimulated students to discuss what was exactly the point of the Comic Strip. They were divided into group which each group consisted of 3 - 4 students. The researcher found out the differences in the next meeting that the Comic Strips helped students to comprehend the text reading a way better than the previous teaching media that used by the teacher. It is supported by Rokhayati and Utari (2014: 147) who stated that the use of Comic Strip as an English teaching media for Junior High School Students was effective. They add that the Comic Strip also has been effective for students' ability in understanding the expression of characters inside the comics.

As in line with Merc, 2013 who investigated the effects of Comic Strips on reading comprehension of Turkish EFL learners. The result shows that all students who were taught by using Comic Strips were better in comprehending the text because it is included visual or the picture in increasing reading comprehension.

Table 5. Students' score in Post-Test

\begin{tabular}{|c|c|c|c|}
\hline No & Nama siswa & J. Nilai & Ket. \\
\hline 1 & AMP & 72 & PASS \\
\hline 2 & AR & 84 & PASS \\
\hline 3 & AS & 76 & PASS \\
\hline 4 & DI & 88 & PASS \\
\hline 5 & FA & 56 & FAIL \\
\hline 6 & HT & 76 & PASS \\
\hline 7 & IW & 52 & FAIL \\
\hline 8 & JA & 84 & PASS \\
\hline 9 & JH & 88 & PASS \\
\hline 10 & KA & 72 & PASS \\
\hline 11 & MHH & 80 & PASS \\
\hline 12 & MU & 80 & PASS \\
\hline 13 & ML & 76 & PASS \\
\hline 14 & SK & 76 & PASS \\
\hline 15 & SN & 76 & PASS \\
\hline 16 & SP & 80 & PASS \\
\hline
\end{tabular}




\begin{tabular}{|c|c|c|c|}
17 & WF & 52 & FAIL \\
\hline 18 & YH & 84 & PASS \\
\hline 19 & ZA & 80 & PASS \\
\hline 20 & QS & 88 & PASS \\
\hline \multicolumn{2}{|c|}{ JUMLAH } & 1520 & \\
\hline
\end{tabular}

Formula:

$$
\overline{\mathrm{X}}=\frac{\sum f i x i}{\sum f i}
$$

Where:

$\overline{\mathrm{X}} \quad$ : the symbol of mean

$\sum \quad$ : the symbol for summation

$x i \quad$ : For any score in the set

fi : Frequency

Answer:

Table 6. Result of Interval Class

\begin{tabular}{ccccc}
\hline Nilai Interval & & $\mathbf{X i}$ & $\mathbf{f i}$ & $\sum$ fixi \\
52 & 59 & 55.5 & 3 & 166.5 \\
60 & 67 & 63.5 & 0 & 0 \\
68 & 75 & 71.5 & 1 & 71.5 \\
76 & 83 & 79.5 & 10 & 795 \\
84 & 91 & 87.5 & 6 & 525 \\
& Jumlah & & 20 & 1558 \\
\hline
\end{tabular}

Based on the used of formula above the result is $X=\frac{1558}{20}=\overline{7} 7.9$. It means that because the result of this research is the comic strip improved students' reading comprehension by using comic strips.

The point of this research is to know or to find out the use of comic strip can improve students' motivation and reading comprehension. After the researcher done conduct this research on MA Raudlatusshibyan NW Belencong researcher got some result. Based on the result of questionnaire, there was improvement of students' motivation in learning reading by using comic strip as the media where classification of 
motivation is divided into four categories, score between $0-25$ was categorized as very low motivation, score between 26-50 is categorized as low motivation, score between 51-75 was categorized as high motivation and the last is 76-100 is very high. Then, the percentage of the questionnaire showed that there was $85 \%$ of highly motivated of students toward using comic strip in teaching-learning reading. Based on the result of data analysis on cycle 1 , it was gotten that the students' highest score was 85 and the lowest score was 61. Overall, in the cycle 1 there were 11 students who got a very high motivation in teaching reading by comic strip and there were 9 students that got high motivation by using comic strip in teaching reading. If we talk about the percentage the researcher could say if this case $55 \%$ got very high motivation and $45 \%$ got a high motivation. In this case, the result of students' average or mean is (75.5\%). From the result of cycle 1, it was shown that by applying comic strip could improve their reading comprehension. It was because of the application of comic strip had given them more support and build students' motivation and in learning English, especially in learning reading in classroom.

In other case, the results of students' reading test were great. The result is 17 of them passed in the reading test and 3 other failed the test. The lower of score is 65 and the higher is 85 score. The researcher could say if from 20 students that as the sample in this researcher $85 \%$ pass from the reading test and $15 \%$ were fail. In this situation also the researcher have to count the average or mean of students from reading test and the result is 77.9. It means that if comic strip could improve students reading comprehension and this research was successful.

\section{CONCLUSION}

The researcher concluded that the use of Comic Strip is able to improve students' motivation and reading comprehension at first grade students of MA. Raudlatusshibyan NW Belencong in academic year 2017/2018. The students' progress during teaching-learning process was better than before the application of Comic stirp. This statement is supported by the result of the mean in post-test at cycle 1 were $85 \%$. From the data calculation shown that by applying Comic strip could improve their 
motivation. It indicated improvement the students' reading comprehension and their motivation of English learning process.

Most of students said that teaching-learning English by comic strip is made student interest and could help them increase their motivation. The main factor was their motivation in English learning by Comic strip for Senior High School and the relevancy between their daily lives in activity. From the explanation above the researcher concluded that Comic strip was suitable for the students at first grade of MA. Raudlatusshibyan NW Belencong.

\section{REFERENCES}

Ahmadi, Muhammad Reza. (2017). The Impact of Motivation in Reading Comprehension. International Journal of Research in English Education (IJREE), 2 (1), 1 - 7. DOI: 10.18869 /acadpub.ijree.2.1.1

Anggraeni, Rahajeng Novita et al. (2015). Improving Students' Writing Skill by Using Comic Strips. English Education Journal , 4 (1), 1-8 DOI: https://doi.org/10.20961/eed.v4i1.34615

Brown, H. Douglas. 2010. Language Assessment-Principles and Classroom Practices. California: Pearson Longman.

Cahyani, Riska Dwi. 2015. Improving Students' Reading Comprehension Through Mind Mapping. Accessed on Friday $1^{\text {st }} 2015$. Sebelas Maret University.

Carry, S. 2014. Going Graphic: Comics at Work in the Multilingual Classroom. Portsmouth, Nh: Heinemann.

Chesla, Elizabeth. 2002. Exam Success in Only 6 Steps. New York: Learning Express.

Costello, Patrick.J.M. 2003. Action Research. British Library.

Darsalina, Lisa et al. (2016). The Application of Comic Strips in Teaching Vocabulary. Research in English and Education Journal, 1 (2), 137 - 145.

Dewi, Hening Yusrika. 2012. "The Use of Comic Strip as Media to Improve the Reading Comprehension of Narrative Text of the Tenth Grade Students of SMA N 1 Karangrayung Purwodadi in the Academic Year 2011/2012”. Unpublished. Muria Kudus University.

Guay. 2010. Intrinsic, Identified, and Controlled Types of Motivation for School Subjects in Young Elementary School Children. The British Psychological Society.

Jere Brophy. 2004. Motivating Student to Learning. Michigan State University.

Levenhagen Matt. 2005. Secrets of Motivation. "III Group of Websites" and is in partnership with "Web Profit School". 
Martages, Ika Fitriana et al. (2017). The Effect of Using Comic Strips on the Eight Grade Students' Narrative Writing Achievement at SMP Negeri 5 Jember. Jurnal Edukasi, 4 (2), 1-3. DOI: https://doi.org/10.19184/jukasi.v4i2.5201

Maulana, Yondrizal and Fitrawati. (2017). Teaching Reading by Using Comic Strips to Improve Junior High School Students' Comprehension. Journal of English Language Teaching (JELT), 6 (1), 124-131. DOI : https://doi.org/10.24036/jelt.v6i1.8535

Pintrich Paul R. 2003. Motivational Science Perspective on the Role of Student Motivation In Learning and Teaching Contexts. University of Michigan.

Pourhosein Gilakjani, A., \& Sabouri, N. B. (2016). How Can Students Improve Their Reading Comprehension Skill? Journal of Studies in Education, 6(2), 229-240. [DOI:10.5296/jse.v6i2.9201]

Rengur, Zul Aini and Sugirin. (2018). The Effectiveness of Using Comic Strips to Increase Students' Reading Comprehension for the Eight Grade Students of SMPN 1 Pondung. Advances in Social Science, Education and Humanities Research (ASSEHR), 330, 239-243.

Rokhayani, Atik and Utari, P. R. A. (2014). The Use of Comic Strips as an English Teaching Media for Junior High School Students. LANGUAGE CIRCEL Journal of Language and Literature, 8 (2), $\begin{array}{llll}143 & -149 .\end{array}$ DOI: https://doi.org/10.15294/lc.v8i2.3018

Snow, Catherine, E. 2002. Reading for Understanding toward an R\&D Programming Reading Comprehension. Arlington: RAND Education.

Stephenson, L. \& Harold, B. 2009. Elements in the Teaching of Reading. Zayed University.

Sugiyono. 2011. Metode Penelitian Kualitatif, Kuantitatif, R\&D. Bandung Alfabeta.

Sumaryanta. 2015. Pedoman Pensekoran. Yogyakarta. Indonesian Digital Journal of Mathematics and Education Volume 2. 